\title{
Port of Antwerp: extension works connected with the Ten Year Scheme
}

\section{G. SCHEPENS}

\section{Mr J. E. G. Palmer, Consultant, Rendel, Palmer \& Tritton}

The dimensions of the whole project are truly staggering, and I should like to highlight one or two points which have particularly struck me. The total length of Canal Docks 1, 2 and 3, plus the three 'finger' basins already built on the western side, provide a total length of about $80000 \mathrm{ft}$ of either already developed wharfage or sloping wall which can be converted into wharfage. No port in the UK can show anything comparable.

77. Another of the staggering features is the enormous volume of dredging. The figure of 70 million cu. yd of dredging in Canal Docks 1 and 2 has been mentioned, but considerable additional dredging was done in Canal Dock 3, making a total in the region of 100 million cu. yd. I suppose that some other country must be responsible for dredging the many miles of the river approach, and I would like to suggest the alternative of putting in a water connexion by canal the whole way from Zandvliet to the sea, entirely in Belgian territory.

78. The Zandvliet Lock is the biggest lock in the world, and although it will not be taking the biggest oil tankers of the future, it should be taking bulk carriers of 175000 tons for many years to come.

79. It is stated in the Paper that after first turning down the proposition that they should lend money to build the project, the Government apparently had second thoughts and passed a law whereby they paid apparently the whole of the cost of the infrastructure, plus $60 \%$ of the cost of the superstructure. One would like to know whether this is reflected in reduced charges levied by the Port of Antwerp. Is the port authority under any obligation to repay any part of this enormous government expenditure, or has it already been paid for out of taxes? If the latter is the case, I suppose that the port dues should be among the lowest in Europe.

80. The Gilsen quay is about $4000 \mathrm{ft}$ long, and during its first two years handled about 250000 tons/year over the equivalent of six berths. This is presumably because the quay has been sublet to a stevedoring company and also no doubt because the apron is of the unusual width of $140 \mathrm{ft}$.

\section{Mr M. Agar, Mersey Docks and Harbour Board}

I should like to refer to some details of the Zandvliet and sea locks and in particular to the gates. It goes without saying that an entrance lock must have facilities which are, as far as is humanly possible, proof against storm damage and ship damage, much more so than those inside a lock system.

82. In Liverpool rolling and sliding gates or caissons are used at our most modern entrance at Longton. Sliding gates suffer the disadvantage of undue wear on the slides, and this is overcome by rollers. However, whilst this overcomes the wear problem, the reduced friction creates a problem of slamming from wave action. We can overcome this by increasing the preponderance on the gates to make them more stable with the use of rollers. We were not able to do it with sliding caissons because the extra weight would in turn cause extra friction and overload the machinery. 


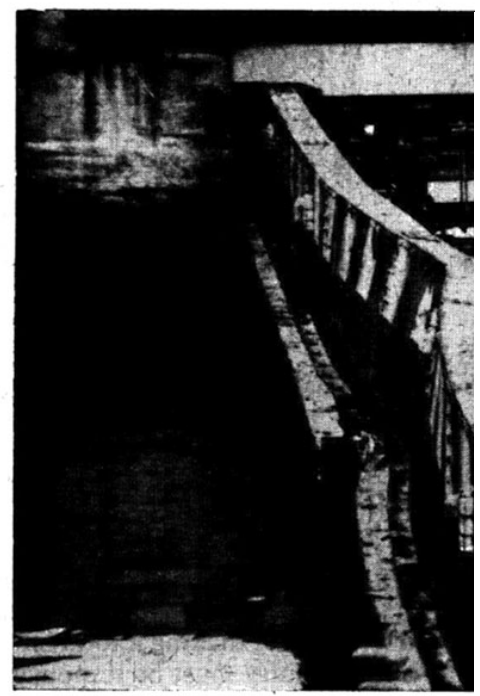

Fig. 13

83. At Liverpool the rollers are all under water but at Zandvliet, with the wheelbarrow arrangement, probably the designers have gone as far as is possible in having all moving parts above water.

84. Our experience is that gates of the caisson type, such as at Zandvliet, are by far the most robust for reducing ship damage. Fig. 13 shows damage as the result of a ship of 6000 tons hitting the caisson at about 4 knots. Although there is a fair amount of damage, it is all above the water line. It did not extend to the buoyancy chambers and-this is the important point-it did not stop the operation of the gate. Any other type of gate would probably have failed under a collision of that magnitude.)

85. It is, of course, a matter of judgement to decide how much spare capacity of gates to allow for overhauls and risk of damage. I notice that at Antwerp all the gates are interchangeable and it might, therefore, be thought that one spare gate rather than two, possibly with two spare chambers, would have been sufficient.

86. Perhaps the Author can give the reasons for the choice of two spare gates.

\section{Mr D. H. Little, W. C. Andrews and Partners, Ltd}

All the structures described in the Paper deal with non-tidal water. I do not think that any of the tide is intended to be let in by the locks. If this is so, I should be interested to know what tidal range or water level range is allowed for in the design of the structures. Are they designed to cater for an accidental complete lowering of the water, or is it a range of level less than the tidal range? If the water is non-tidal, as I believe it is, I am a little surprised that more use was not made of steel sheet piling. I wonder if there is any particular reason for this.

88. I was particularly interested to see that so much use has been made of mass concrete. A graving dock with which I was associated would have been $1200 \mathrm{ft}$ long, $150 \mathrm{ft}$ wide and $68 \mathrm{ft} 6 \mathrm{in}$. from coping to foor. It would, of course, have been capable of being pumped empty, which is a different proposition from the huge lock at Antwerp which, I assume, can never be dried out.

89. Although a lot of other people tried to prove it otherwise, I found that a mass concrete design was the cheapest that we could produce. I am, therefore, particularly 
interested in mass concrete work, and the rate at which the concrete was poured (upwards of $2000 \mathrm{cu}$. yd/day) amazes me. I would like to know whether any limit was placed upon the amount of concrete in any one pour and also whether vertical joints were formed in the walls, at what intervals they were formed, and whether it was necessary to make those joints watertight.

90. Reference is made in the Paper to the fact that the concrete was carried in trucks. I wonder whether that means that they were open trucks. Reference is also made to the fact that the concrete was grabbed out when placed. Was the concrete taken to the site in skips and then lowered, or was it taken in open trucks and actually grabbed out?

91. I would like to know why reinforced concrete was used in the big lock and what stresses were used in the concrete and the steel. Was any particular cover given to the steel? In a graving dock design with which I was associated, in order to get a reinforced concrete design of nearly the same strength as the mass, high tensile steel had to be assumed with high stresses in the concrete without any regard to the effect of salt water. It would interest me to know what stresses were used in the steel and in the concrete in this design.

92. I notice from one of the illustrations that the coping was overhung a little to help to form a cushion of water as a fender. I wonder whether this is necessary, and if its effectiveness has been proved in use.

\section{Sir Harold Harding, Past President}

I visited Antwerp in 1932 to see the deep well ground water lowering carried out by Siemens Bau Union following their work at Southampton graving dock.

94. In $\$ 11$ the Author mentions ground water lowering and states that 'due to the proximity of an existing dock, the use of ground water lowering pumps could not be expected to yield satisfactory results'. Why was this so, and does permeable sand exist for considerable depths under all the works?

95. The Canal B1-B2 is a long ship canal. Is this intended to take shipping all the way from the big Zandvliet Lock to the other docks in order to save enlarging the upstream entrances, or is it to save dredging in the Scheldt as far as those entrances?

96. Does most of the ground in the area consist of sand? The Thames estuary suffers from $40 \mathrm{ft}$ or more of estuarine clay and peat, which is a less useful material than the Dutch and Belgian sands.

97. How will Antwerp compete with the new Europoort, or will they both prosper at the expense of the Port of London?

98. Dr Kjellman showed me his cardboard wick drains in 1947 in Sweden, when they were being used to accelerate settlement in glacial silt for an airfield. There was one simple prototype machine at work and a highly developed machine with automatic control for forward movement at fixed distances. It would be interesting to know what machine was used at Antwerp. Is the combination of cardboard wicks with electro-osmosis original? The latter method was tried after the war with the help of Mr Leo Casagrande, but in British conditions beds of gravel are apt to occur in the soft clays and hinder the success of the method.

99. The Paper does not say if deep wells were used to construct the Zandvliet Lock. At Southampton the excavation for the graving dock was $100 \mathrm{ft}$ deep and the Bracklesham sands below contained water under artesian head of $200 \mathrm{ft}$ rising to $13 \mathrm{ft}$ above ground level in the trial boreholes. The concrete floor of the dock was $30 \mathrm{ft}$ thick with relief wells left in the walls. One assumes that the Zandvliet Lock will never be dewatered, which explains the thinness of the floor.

Professor A. L. L. Baker, Imperial College

I must reply to the remarks concerning reinforced concrete. I was brought up in a reinforced concrete firm, Cristiani \& Nielsen, and later with an oil company. In both 
these firms we could not simply go to consultants and ask them to design a jetty. We had to provide them at minimum cost. It is curious that practically all the oil jetties built since about 1930 have been of open pile construction.

101. I know the choice of design depends a great deal on how the cost of mass concrete and reinforced concrete compare, and perhaps on whether a suitable pile frame is available. The factor of plant availability in regard to economy is of ten very much more important than whether one skimps the section of the piles or uses high tensile steel.

102. To refer to the Paper, I would like to ask what were the principal factors which influenced the design of the various quay walls. Some are solid mass concrete right to the foundation. Some are mass concrete down to low tide level and from there onwards there are systems of raking and vertical piles.

103. In the case of the tanker berths, which are in very calm water and well protected, there are solid caissons right to the foundation, with fill between. I take it that there was plenty of fill available, probably from dredging, and that mass concrete was found to be cheaper than a raking pile system with a reinforced concrete deck, which has been found for some time in Britain to be the cheapest way to construct an oil berth, with suitable fendering in exposed positions.

\section{Mr E. Newton, Port of London Authority}

I would like to ask the Author to give some additional details of the Zandvliet Lock, which is not only the largest lock in Europe (and perhaps anywhere) completed to date, but also a very interesting structure. The lock walls and floor appear to have been designed for maximum economy in materials, in contrast to the mass concrete gravity walls of the new docks. Could some indication be given of the cut-off between lock and dock, of the cost of the lock and of any Belgian publication which describes its design and construction?

105. It may be of interest to compare the leading dimensions of the Zandvliet Lock with the locks now under construction at Dunkirk and Le Havre.

\begin{tabular}{|c|c|c|c|}
\hline & $\begin{array}{l}\text { Zandvliet Lock } \\
f t\end{array}$ & $\underset{f t}{\text { Dunkirk }^{1}}$ & $\underset{f t}{\operatorname{Le} \operatorname{Havre}^{2 *}}$ \\
\hline $\begin{array}{l}\text { Length between outer gates } \\
\text { Width } \\
\text { Depth of water over the sills (Mean } \\
\text { High Water Neaps (approx.)) } \\
\text { Depth of water over the sills (Mean } \\
\text { High Water Springs (approx.)) }\end{array}$ & $\begin{array}{r}1547 \\
187 \\
56 \\
58\end{array}$ & $\begin{array}{r}1200 \\
165 \\
60 \\
63\end{array}$ & $\begin{array}{r}1312 \\
190 \\
63 \\
66\end{array}$ \\
\hline 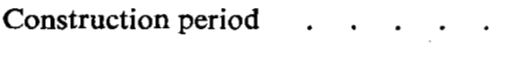 & $1961-1967$ & $\begin{array}{c}1966-1971 \\
\text { (estimated) }\end{array}$ & $\begin{array}{c}1967-1971 \\
\text { (estimated) }\end{array}$ \\
\hline
\end{tabular}

106. All three locks are designed to have pairs of rolling caisson gates at each end, thus providing $100 \%$ stand-by and in-situ gate repair facilities and the planners of the Zandvliet Lock must be congratulated on the success of their concept, which seems to have gained wide acceptance on the Continent. At Antwerp and Dunkirk there are other locks which can be used by smaller ships and craft, and at Le Havre a smaller lock may be built later alongside the principal new lock to improve access to the new dock. However, a fifth gate somewhere along the Zandvliet Lock would have made

* The dimensions given in ref. 2 have been modified. Those given here are correct. 
the lock rather more flexible and economical in operation at an additional cost of about $5-10 \%$ of the total. Has this been considered?

107. The French authorities have estimated the cost of the locks at Dunkirk and Le Havre to be between $£ 15000000$ and $£ 17500000$ per lock. These locks are designed as mass concrete gravity structures, and no doubt the Zandvliet Lock cost less. However, these figures are indicative of the price the major Continental ports-or their respective governments-are prepared to pay in order to provide a lock for ships of up to $150000 \mathrm{dwt}$.

108. A figure of $£ 6000000$ for a new major lock in the United Kingdom has been mentioned on occasions, but this would not seem realistic. The leading dimensions of the four principal existing locks in this country are as follows:

\begin{tabular}{l|c|c|c|c}
\hline & \multicolumn{2}{|c|}{ London } & \multicolumn{2}{c}{ Liverpool } \\
\cline { 2 - 5 } & $\begin{array}{c}\text { King George V } \\
\text { Lock, } \\
\text { Royal Docks } \\
f t\end{array}$ & $\begin{array}{c}\text { Western } \\
\text { entrance, } \\
\text { Tilbury } \\
f t\end{array}$ & $\begin{array}{c}\text { Gladstone } \\
\text { Lock }\end{array}$ & $\begin{array}{c}\text { Longton } \\
\text { River } \\
\text { entrance } \\
f t\end{array}$ \\
\hline $\begin{array}{c}\text { Length between outer gates } \\
\text { Width . }\end{array}$ & 800 & 1000 & 1070 & 825 \\
$\begin{array}{c}\text { Depth of water over the sills } \\
\text { (Mean High Water Neaps) }\end{array}$ & 100 & 110 & 130 & 130 \\
$\begin{array}{c}\text { Depth of water over the sills } \\
\text { (Mean High Water Springs) }\end{array}$ & 42 & $42 \frac{1}{2}$ & 43 & 42 \\
\hline
\end{tabular}

The maximum draught of ships using these locks does not at present exceed 34-36 ft. However, the trend towards larger ship sizes and the provision of three major new locks on the other side of the Channel may substantially alter the pattern of deep sea traffic in the next decade.

109. The Port of Antwerp has, with great foresight, provided far greater depth in the Zandvliet Lock and the new docks than is at present available in the Scheldt. Could the Author give an indication of the dredging programme envisaged in the approaches to the Zandvliet Lock?

110. The Port of Rotterdam will be ready to receive tankers of up to $225000 \mathrm{dwt}$ by 1970, and it is unlikely that the Port of Antwerp will be able to accommodate tankers of more than $125000 \mathrm{dwt}$ after completion of its dredging programme. How will this affect the position of Antwerp as a major direct import terminal for its own refineries and petrochemical industry? In 1956 Europe had only 500 miles of pipelines; now there are 4500 miles. $^{3}$ Does the Author think that Antwerp may soon be linked by pipeline to one of the major French oil ports?

111. In $\S 34$ the water depth of the Sixth Dock is given as $80 \mathrm{ft}$; this would seem to be an error as the depth shown in Fig. 8 is $50 \mathrm{ft}$. Could the Author provide a plan of the whole of the Port of Antwerp, the old and the new, to show the extent of the works in relation to the Port as a whole?

Mr R. A. Fisher, British Transport Docks Board, Hull

A very strong impression has been created by the Paper of the tremendous size and scope of these works, with the vast quantities of materials which have been moved, but there are also several indications of a modern scientific approach and attitude towards certain details.

113. To give an instance, there is mention towards the end of the Paper of the pit which has been excavated on the canal side of the Zandvliet Lock to absorb the salt 
water (or at least that amount of the water entering the dock which is of a greater salinity than the rest) and sluicing it out back into the River Scheldt, presumably in an attempt to diminish siltation problems in the new dock system.

114. I would like to refer, as other speakers have done, to the desire to see more details, particularly with regard to the construction and the design of the lock pit itself. It seems to me that having made scientific investigations into such things as desiltation measures the Author would also have undertaken a number of exercises into such matters as the layout of the sluices and culverting systems. For example, it is mentioned in the Paper that the lock pit can be filled in about $15 \mathrm{~min}$. Does the system which has been adopted provide the quickest means of filling the lock pit, or were other systems investigated which could have filled it more quickly, but which had disadvantages in other respects?

115. Several speakers have referred to the caisson gates, and I am sure that alternatives must have been considered at one time or another. There are duplicate gates in each position which must be a very expensive item. It has also been necessary to provide for a means of underwater inspection of the rails, where they run across the bottom of the lock pit, and means of shutting off the recesses into which the caisson gates move back. These facilities together with the de-watering pits indicate an expensive maintenance involvement on this type of gate and more information would be most valuable.

\section{Mr F. A. Page, Port of London Authority}

I was very interested to see that for the greater part of the Antwerp quay walls a gravity design had been adopted, particularly so as the section bears a striking resemblance to walls which were being built in the Port of London at the turn of the century. One of these old walls, constructed to provide over $40 \mathrm{ft}$ depth of water, had a height of $53 \mathrm{ft}$ and a base width of $27 \mathrm{ft}$ in soil conditions possibly more difficult than at Antwerp. These proportions are very similar to those described in the Paper and it is a compliment to the engineers of those days that a modern wall, rigorously designed, should tend to confirm work that was built so long ago.

117. With the design of quay walls the nature of the soil conditions and the question as to whether or not it is possible to de-water cheaply very largely dictate the kind of construction adopted. The sand at Antwerp seems to be capable of being dewatered with reasonable ease although the Paper gives no details of this. At the Port of Dunkirk where soil conditions were probably similar, the new quay walls are generally of circular concrete caissons sunk from ground level, only limited ground water lowering being necessary. Presumably the difficulties of de-watering at Dunkirk were considerably greater than Antwerp and this probably dictated the choice of a more expensive type of construction.

118. About 10 years ago, a well-point de-watering system was used for the reconstruction of an entrance lock in the Port of London. In this case the recovery of the full head of ground water occurred within half an hour of the pumps stopping, and duplication of the pump units and power supply was needed. Presumably the conditions at Antwerp were not as difficult and extensive standby plant to cater for possible breakdowns may not have been needed. It would be interesting to know the extent to which possible breakdown of pumping plant had to be catered for and the cost which was involved.

119. At Tilbury we tried to get a better idea of the soil pressures exerted on the back of the monolith quay wall and some earth pressure cells were inserted in the backs of the monoliths. The results were a little inconclusive but they were useful. Were any similar attempts made at Antwerp to measure actual pressure rather than to rely entirely on results deduced from soil mechanics data? With the pressure cells there is a problem of differentiating between active or passive pressure; 
they can be fastened to sheet piled walls and, if placed at a point of maximum deflexion, active pressures would probably be recorded.

120. The Kjellman drains to which reference has been made are very interesting, and this is the first reported use of them that $I$ have seen. The Author has given a number of details but it would be useful to know in addition the particle size of the soil which was stabilized in this manner and the cost incurred.

121. The use of a perforated bottom for the Zandvliet Lock where there is a tida range of $16 \mathrm{ft}$ is an unusual feature. I understand that this form of construction was also used for the Baudouin Lock and it may be that this construction has been developed over a long period. Presumably a cut-off was used to prevent the development of subterranean drains beneath the reinforced concrete walls to avoid the possibility of leaching and settlement.

122. There are, of course, a number of items of major engineering significance which are not detailed in the Paper, one of which is the rail bridge over the Canal Dock. This must be one of the biggest bridges of the Strauss type to be constructed to date. It will be interesting to know why this type of bridge was used rather than, for example, a trunnion bascule, as there appears to be adequate clearance for a low hung counterweight. With a bridge of this span a centre connexion between the leaves would be necessary. In this case was a simple shear or a moment connexion provided?

\section{Written contribution:}

\section{Mr D. G. McGarey, Chief Engineer, British Transport Docks Board}

I would like to express my gratitude to Mr Schepens for his absorbing Paper. I am grateful, also, to Mr Schepens for having translated all his dimensions into British units.

124. In Great Britain the vital importance of the Port of Antwerp to the whole national economy of Belgium is appreciated. It is probably not too wide of the mark to say that, as Rotterdam is to Holland so is Antwerp to Belgium. This enables us to understand the motive behind such a very ambitious development-a national determination to make its chief port as attractive as possible, in comparison with neighbouring ports of other countries, as a main terminal for the trade of the NW sector of the Continent of Europe. With this in mind the British port engineer cannot fail to be envious of the extent to which government encouragement and financial support is given in Belgium, as outlined in $\$ 3-8$. It is, of course, true that in Great Britain financial assistance to the extent of $20 \%$ of the cost of development works is given in many cases, and any substantial subsidy might only lead to an intensification of competition between ports serving broadly the same limited hinterland and the same national economy.

125. On the question of costs, one is naturally tempted to make a comparison between the Antwerp developments and those of the PLA at Tilbury. From the limited data relating to overall costs it would seem that the relatively simple dock extension at Tilbury in the form of one arm about 1 mile long $\times \frac{1}{8}$ mile wide has cost about $£ 20$ million, the 'extras' having included an impounding station, roll-on/roll-off berths and some sheds, but no lock entrance. At Antwerp, on the other hand, the Fifth and Sixth Docks are each comparable in size to the Tilbury Extension, in addition to which there are three Canal Docks, totalling some 6 miles in length $\times \frac{1}{4}$ mile wide (including also the Lillo tunnel and bridge) and the gigantic Zandvliet Lock-all apparently for a cost of less than $£ 40$ million.

126. However rough and incomplete the cost figures may be, there is clearly no comparison between the two schemes and it would have been very interesting if Mr Schepens could have given more details. No breakdown is given, for example, either of the lock costs (what is included in the figure of $f 6.338$ million and what was 
the actual cost ?) or of the massive quay walls of the Canal Docks. During construction one was particularly impressed by the methods adopted for building these lengthy quay walls where, once the de-watering problems had been solved, the use of continuous processes in excavation, shuttering and concreting must have contributed very materially to the low costs that were undoubtedly achieved. For this reason it would have been of great value if at least the figures comparable with those given in $\$ 182$ of the paper on Tilbury ${ }^{4}$ could have been given.

127. One might be tempted to ask if a fully impounded dock system is justifiable for a location served by a river having a maximum tidal range of only $13 \mathrm{ft} 2 \mathrm{in}$. In Britain this would be comfortably within the range normally considered suitable for a system of tidal berths, as at Southampton for example. At Antwerp, however, it would clearly not have been practicable to accommodate upwards of 12 miles of quay on the one river bank, and siltation difficulties would probably have militated against any idea of tidal branch docks. Further, it seems that even the heavy cost of the Zandvliet Lock, when spread over the ultimate total length of quay walls in the Canal Docks alone, would be less than $£ 100 / \mathrm{ft}$ run of quay. The extra costs of deepening both the wall structures and the water space in front for tidal berths, even with the low unit costs referred to above, are unlikely, one supposes, to have been less than such a figure.

128. The Canal Docks appear to offer almost limitless possibilities for future development. Although it is noted from $\$ 59$ that the lateral extension docks have already been allocated, it would be interesting to know how far definite uses can be foreseen for all the main quay walls (both as now constructed and as projected for the future), for the extension B3, and also to know the purpose of the embayment in B1.

129. As regards the maximum size of ship capable of being accommodated in the new system, it seems that, although the oil jetties south of the Van Cauwelaert and the Baudouin Locks have only $50 \mathrm{ft}$ of water, the Canal Docks will have not less than $55 \mathrm{ft}$ with a presumed maximum of $58 \mathrm{ft}$ to match the Zandvliet Lock. There would thus be scope for vessels of up to about $52 \mathrm{ft}$ draught, represented by tankers of about $150000 \mathrm{dwt}$ capacity.

130. Finally, some description of the impounding installation and pumps referred to in $\S 4(e)$ would be appreciated. Again, one would like to make a comparison with the Tilbury installation, where it is interesting to note that the designed pumping rate is nearly twice that quoted for Antwerp.

131. It is hoped that $\mathrm{Mr}$ Schepens will accept these indications of a thirst for knowledge as a testimony to the very great interest taken in Britain in the outstanding development works he has been responsible for in Belgium.

\section{Mr G. Schepens*}

It is gratifying to the Author that many questions should be asked on his Paper, in which there appears to be great interest. It was not the intention to include the full details of all constructions carried out during the Ten Year Scheme. That would have been quite impossible.

133. To remove any misunderstanding concerning the Zandvliet project, it must be said that the project, and the design and details of the lock, originated from Government engineers in the Ministry of Public Works. The Zandvliet Lock was, however, a gift from the Government to the City of Antwerp.

134. Mr Palmer spoke about dredging of the river. The dredging in the docks in the port is done by the technical service of the City of Antwerp, but the dredging of the river is done by the Government. The depth of water in the river allows the

* Mr Schepens was unable to attend the meeting, at which replies were made by Mr M. de Wilde, Chief Engineer, Civil Engineering Section, Technical Service of the Port of Antwerp, and Mr F. van Orshaegen, Counsellor, General Management, Port of Antwerp. Their remarks are incorporated into this reply. 
entrance of ships with a depth of $42 \mathrm{ft}$ and a burden of about $70000 \mathrm{dwt}$. Tests have been done in the laboratory at Borgerhout, Antwerp, and it is hoped to normalize the river and to obtain a fairway for ships with a depth of up to $45 \mathrm{ft}$ for a tonnage of $85000 \mathrm{dwt}$. That will be the first stage. We have higher figures for our new docks, and we hope that the depth of $45 \mathrm{ft}$ may be increased.

135. The reasons for having two spare gates for the Zandvliet Lock are that after completion of the work, the construction of a fourth gate room would be either impossible or extremely expensive. We have, therefore, provided two spare gates. If there is damage to one of three gates and a gate is out of service for maintenance, it is not very easy to bring the gate into service for several days, which would represent a considerable loss. At present, Antwerp handles 18250 sea-going ships/year, or about $60 /$ day. If we had to work day and night for three or four days, this would represent a handicap of 240 ships during that period, which would be more than the costs of a fourth gate.

136. The water level in the docks is almost constant. Any variation would be a difference only of inches. Therefore no allowance is made for tidal range or difference in the water level in the calculations for the quay walls. To have done so might have doubled the costs of the walls, which we could not afford. For that reason, and also in case of accident at the lock gates, it is better to have two spare gates at each lock.

137. For the construction of the massive concrete walls no limit was placed upon the amount of concrete in any one pour, but vertical joints were formed in the walls at intervals of $20 \mathrm{~m}$ (about $67 \mathrm{ft}$ ). The concrete was taken to the site in open trucks and grabbed out. As there is no tidal range in the docks, watertight joints were not necessary because the ground water level behind the walls is nearly the same as the water level in the docks.

138. No earth pressure cells were inserted on the back of the monolith walls. Reinforced concrete was used for the Zandvliet Lock because it was the cheapest construction. The stresses are: concrete, $50 \mathrm{~kg} / \mathrm{sq} . \mathrm{cm}$ (711 lb/sq. in.); steel, $1200 \mathrm{~kg} / \mathrm{sq} . \mathrm{cm}(17065 \mathrm{lb} / \mathrm{sq}$. in.). Steel sheet piling was used as a cut-off to prevent the development of subterranean drains beneath the reinforced concrete walls and to avoid the possibility of leaching and settlement.

139. Ground water lowering by means of deep well pumps in permeable sand in close proximity to the Fourth Dock, where the transition wall was built, could not be expected to be very satisfactory due to water infiltration, and for that reason a junction wall on a high level foundation down to the water level in the existing dock was designed. Canal Docks B1-B2, being a link between the Zandvliet Lock and Hansa Dock, give access to the largest ships ever to call at the port; they shorten the distance to the North Sea by about $9.5 \mathrm{~km}$, and save extra dredging in the Scheldt between Zandvliet Lock and Boudouin Lock.

140. Sir Harold Harding asked for details of the machine to drive the wicks of the Kjellman drains into the ground. The machine is the property of the Contractor (Frankipiles). The water in the neighbourhood of the cathodes, as the Paper indicates, was removed by deep well pumps in filter tubes. For the construction of the Zandvliet Lock, deep well pumps were also used.

141. The method of construction of the massive concrete walls differs from port to port, city to city, country to country and from one group of engineers to another. We have a good sandy soil for the quay walls. There is no tidal range in the docks and we have considered several types of wall. The locks are another question. The water level in the docks is constant. We have calculated different types of quay walls, and the cheapest type was the massive wall.

142. The jetties are different. The first jetty which we built in the access channel to the Petroleum Dock was of massive construction type with sand filling between the walls. The construction of the second jetty was done on piles, because at that moment in time this happened to be a cheaper method of construction. We do not 
name the price. The contractors do that. The construction in 1960 might have been for a jetty and not for a quay wall. At that moment, the construction of massive quay walls was cheaper. In 1964 construction with piles was cheaper, because the contractor's price for this method of construction was lower. This is not a question of engineering. It is a question of price, which can be answered by the contractors. We always try to get the cheapest construction.

143. Mr Newton is right in suggesting that there is an error in $\S 34$; the depth of water referred to should be $50 \mathrm{ft}$ and not $80 \mathrm{ft}$. The depth of $50 \mathrm{ft}$ is referred to also in $\S 36$.

144. The project and the design of the Zandvliet Lock were prepared by our colleagues in the Ministry. The lock was projected for two different methods of use. The first was to accommodate four ships of $30000 \mathrm{dwt}$ each, sluicing at the same time, and the second was to accommodate one ship of $100000 \mathrm{dwt}$. Therefore, if the dimensions of length and width are not exactly in accordance with the depth, that is the reason.

145. The construction of Canal Dock B1 was limited by the Verlegde Schijns, two moats which diverted the waters of the low level area north of Antwerp into the river Scheldt.

146. The construction of a pumping station and the installation of the forcedflow ducts connected with it were intended

(a) to replace the existing water outlet to the Scheldt by a new one in order to put an end to the influence of tidal range in the river;

(b) to create a shorter course for the Schijns arms, so that these would no longer constitute a hindrance to the establishment of industrial sites along Canal Docks B1-B2.

147. The pumping station (Fig. 14) is equipped with five pumps each of $4 \mathrm{cu} . \mathrm{m} / \mathrm{s}$ capacity, at a medium lifting height of $9.20 \mathrm{~m}$ at optimal output ratio. This nominal flow per pump permits a lowering of the water level by $1 \mathrm{~m}$ in one of the arms after $7 \mathrm{~h}$ of pumping. The installation of the pumping station involved modifications to the course of the moats, as the existing outlet had to remain in service up to the moment when the pumping station was brought into operation, and furthermore, the waters of both arms had to be kept fully separated, the degree of pollution being very different. One of the moats carries virtually unpolluted rainwater, which can be brought directly into the Canal Dock, while the other carries polluted sewerage waters, to be pumped into the Scheldt.

148. The course of the ducts, which, except for the zone under the bottom of the Canal Dock, rest on reinforced concrete yokes and Frankipiles, was designed so as to obtain a minimal length and minimal hydraulic losses and to keep the output as favourable as possible. Five ducts, $1.50 \mathrm{~m}$ i.d., each connected to a pump with a nominal capacity of $4 \mathrm{cu} . \mathrm{m} / \mathrm{s}$, originate from the pumping station. They run almost horizontally up to the valve house (east of the Canal Dock), where all possible measures are taken to pump the water of the second mentioned moat as well into the Canal Dock; this will be done in the future, when a clearing station will be in operation. To that purpose, eight ducts leave the valve house, of which five are connected directly to a flow-breaking chamber built into the quay wall. The other three pass underneath the quay wall and the Canal Dock to the western bank, from where they continue towards the Scheldt. These works required $1975 \mathrm{~m}$ of steel piping, $1.50 \mathrm{~m}$ i.d. and $6415 \mathrm{~m}$ of reinforced concrete piping, provided with an inner lining of steel, of the same diameter.

149. The first stage included the ducts between the Scheldt and the eastern quay wall of Canal Dock B1, and the construction of the outlet itself. The second stage mainly comprised the second part of the ducts, between Canal Dock B1 and the pumping station, the pumping station itself, the effluent ditches, the valve house east of Canal Dock B1, the electromechanical equipment, the electric installations (high 

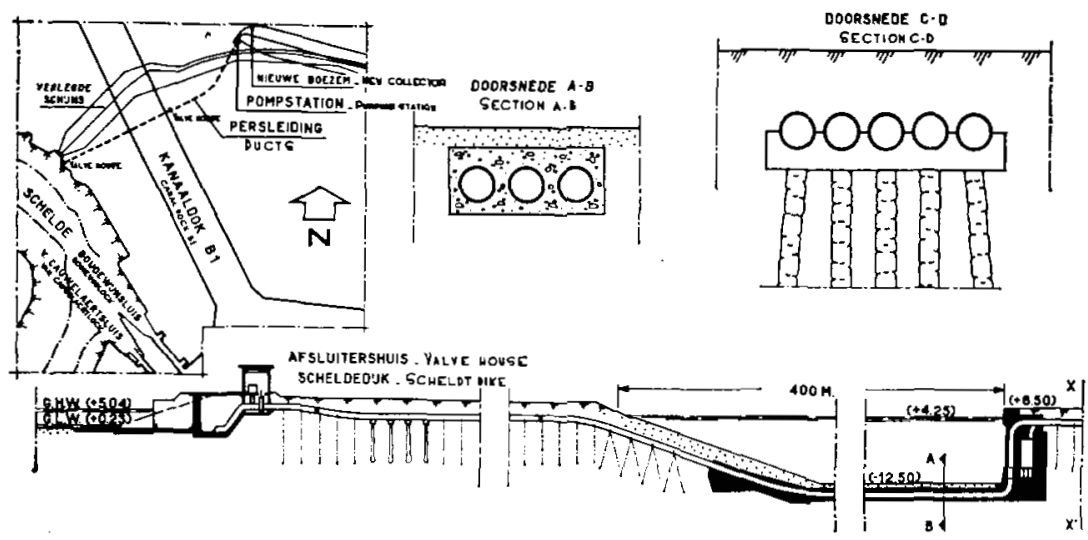

LANGSE DOORSNEOE OVER DE PERSLEIOHNO

LOMEITUDINAL SEENON OF DHE FOACED. HON OUCTS

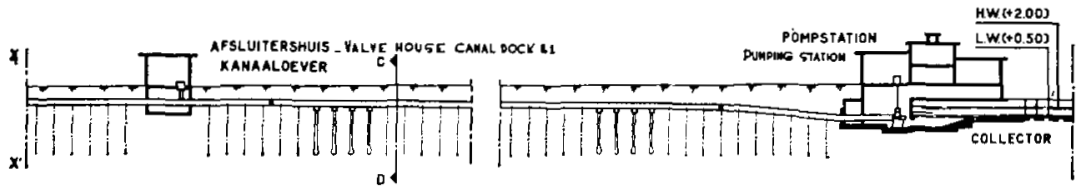

Fig. 14. Pumping station

and low tension, and lighting) and twin houses for the personnel connected with exploitation.

150. The five pumps (each $620 \mathrm{hp}$ ) are automatically switched on by level meters in each of the moats. They are of the half-centrifugal type, directly driven by a vertical asynchrone motor with short-circuited rotor, fed at $6000 \mathrm{~V}$, starting at reduced tension over a starting transformer.

151. Each of the five forced flow ducts has behind the pump a single-direction valve, $1400 \mathrm{~mm}$ in dia., of the tilting disc type (pivoting at about $\frac{2}{3}$ height), a butterfiy valve and a flow meter of adapted construction, $1500 \mathrm{~mm}$ in dia. Eight butterfly valves are installed in the valve house, on the eastern bank of Canal Dock B1, with remote control from the pumping station, which allows the water to flow in any chosen direction. In valve house 2 , on the Scheldt dike, a telecontrolled sliding valve is installed in each of the three ducts. In both valve houses vacuum pumps remove the gas bubbles from the highest parts of the ducts.

152. In the pumping station two emergency diesel groups $(6600 \mathrm{~V}, 1200 \mathrm{hp})$, which can each feed one pump are also installed, and one emergency diesel group $(380 \mathrm{~V}, 250 \mathrm{~kW})$. All buildings are equipped with overhead travelling bridges, mostly electrically powered. In principle the pumping station functions fully automatically. However, two guards effect a permanent control.

153. The third stage mainly included the high tension installation: high tension feeding is effected under a nominal tension of $15500 \mathrm{~V} \pm 5 \%$ by means of two cables (one of them spare) of $3 \times 150$ sq. $\mathrm{mm}$.

154. Further details have been requested of the construction of the canal bridge. Although it was conceived originally as a bridge for railway traffic between both banks of the canal, it was decided at a later juncture (owing to the period of execution 


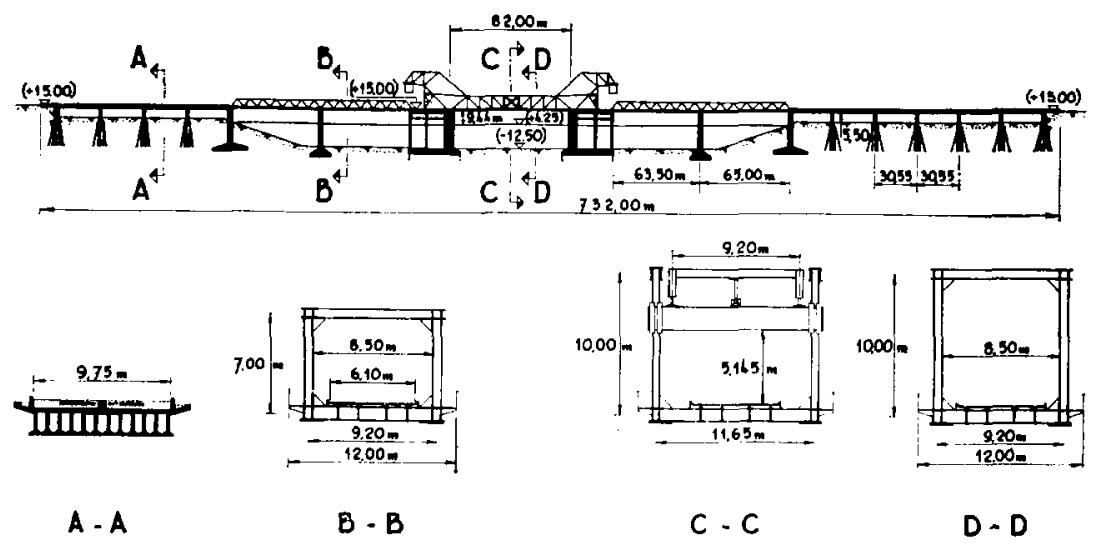

Fig. 15. Double drawbridge : railway and road

required for the building of the tunnel), to provide the bridge construction with a definite road surface also. In addition to a double railway track, a road surface will also be laid out, with a width of $9.80 \mathrm{~m}(32 \mathrm{ft})$ on the bridges in prestressed concrete and of $6 \mathrm{~m}$ (20 ft) on the steel spans (Fig. 15). The level of the upper side of the rails and of the road surface was fixed at $+15.00 \mathrm{~m}(49 \cdot 2 \mathrm{ft})$ with the purpose of reaching

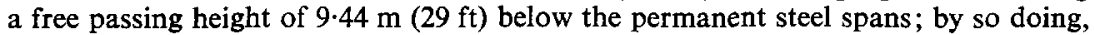
the concrete bridges on the banks still leave a free passing height for the road traffic of $5.50 \mathrm{~m}(18 \mathrm{ft})$.

155. Arrangements, as made, thus permit

(a) uninterrupted passing underneath the permanent steel bridges for inland craft;

(b) laying out continuous roads free from crossings along both banks, for roadtraffic.

The main elements of the work carried out are as follows.

156. Bridges for access, on the banks, in prestressed concrete. As shown by the longitudinal section, this means a continuous bridge construction supported on both banks by a number of intermediate pillars. Each span is made up of 12 prefabricated prestressed girders (inverted T-shape), having a length of $\pm 30 \mathrm{~m}$ (weighing 22 tons), brought by road. The overall bearing is Neoprene, three layers $10 \mathrm{~mm}(0 \cdot 4$ in.) thick. After being placed, the girders are prestressed athwartly and united into one continuous construction by means of a concrete plate having a thickness of $\pm 25 \mathrm{~cm}$ (10 in.) cast on top.

157. Permanent steel spans of access bridge to double drawbridge. This consists in each case of a continuous steel bridge of the Warren type above both banks. The fixed bearings are on the side of the movable part on the central abutments. For the construction of this bridge (total weight to be mounted, $838000 \mathrm{~kg}$ ), about 650 tons of A52 grade II steel were used together with 158 tons of A37 SC. The assembly on site was carried out with bolts of high tensile strength.

158. Basculating spans. As shown on the sketch, the central fairway is spanned by a double Strauss bridge; the centre connexion between the leaves is a moment connexion. About 2000 tons of steel (quality A37 and A52) are being used for it. On 15 December, 1966, some 1500 tons had been brought to the site and 1317 tons were completely assembled. The assembling of the bridge was carried out in units 
of \pm 60 tons, which had been pre-assembled in the workshop and brought to the site by water. In general high tensile bolts were used in assembly both in the workshop and on site.

159. Work started on 25 January, 1965, and the bridge construction, including the slopes for access, was completed for traffic on $18 \mathrm{July,} 1967$.

160. A summary of the actual costs of the port scheme at Antwerp are given in Table 1.

Table 1. Summary of actual costs

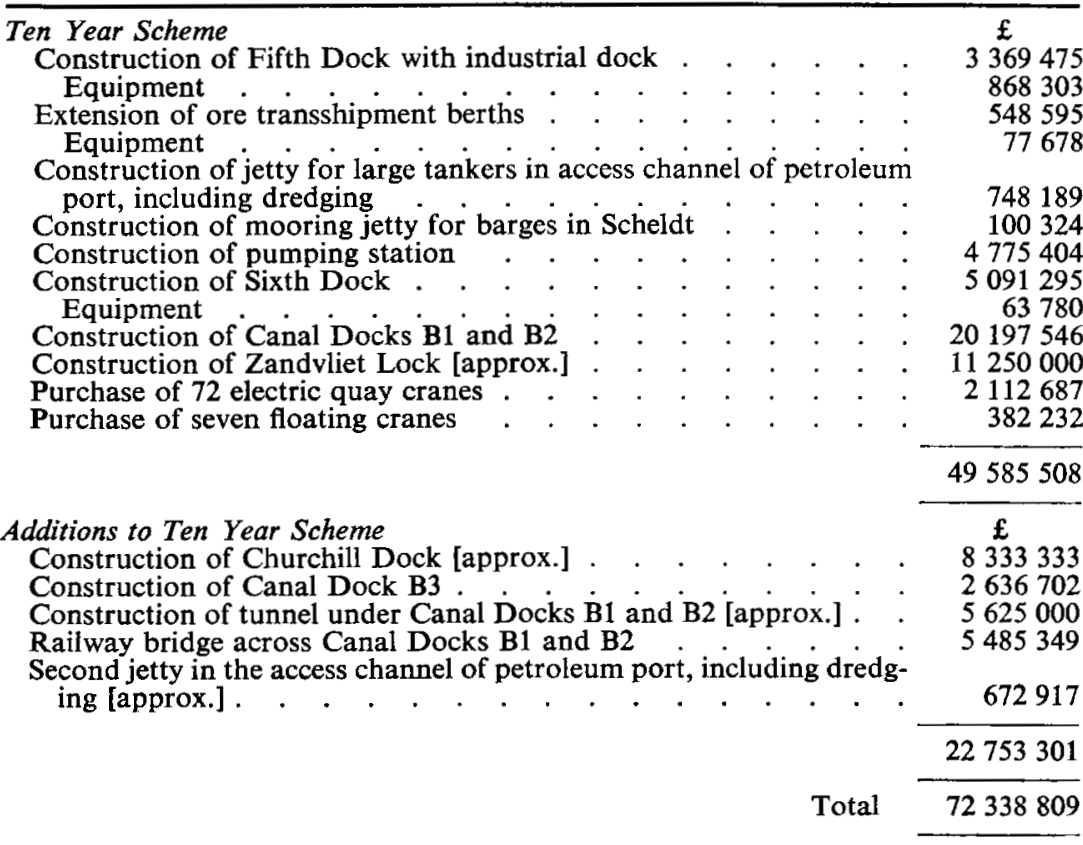

$£ 1=120 \mathrm{BF}$.

161. The rate of development at Antwerp has been startling over the past few years and there has been a veritable flood of foreign investment in the area, especially since the signing of the Treaty of Rome in 1957. In fact, during the past eight years foreign groups and companies decided to make investments in Belgium amounting to approximately 76000 million Belgian francs (BF), or an average of 9500 million $\mathrm{BF} /$ year. Proportionally speaking, these are large amounts and considerable investments, as they represent as much as $20 \%$ of the total gross capital investment in the industrial sector. A large part of this foreign investment came to Antwerp, and more especially to the port and mainly to the industrial area of the port of Antwerp.

162. Large seaports indeed have now ceased to be merely places where goods are transshipped, stored and distributed. Their function as a port is of course being developed further, but they have been gaining an industrial function in addition. In the North Sea ports on the Continent, this growth has come about at an accelerated pace, and over only a relatively short period of time. River deltas, such as those of the Scheldt/Meuse/Rhine, also the Rhone delta, have been developed by local, regional and government authorities, and are proposed by them as poles of growth for 
the furtherance of industries. Nearly every continental port endeavours to open up sites for industrial settlement.

163. The scale of increase which showed itself as a consequence of the setting up of the European Economic Community, both in production and consumption in the outlet possibilities, exercised an attraction, which is not to be underestimated, not merely on industry inside the Euromarket, but also, and more particularly, on American industry eager to acquire a greater portion of the European market.

164. Antwerp, by its Ten Year Plan for expansion and modernization, was able to welcome large industrial enterprises at the very moment the phenomenon of the increasing industrialization of the main seaports took place. The Ten Year Scheme indeed provides for large industrial areas in a completely new industrial zone along the $10 \mathrm{~km}$ long Canal Dock and the Churchill Dock.

165. The following countries have made the biggest industrial investments in the port of Antwerp during the period 1960-67:

$\begin{array}{lrr} & & \text { BF } \\ \text { USA : . } & \text { - } & 17352 \text { million } \\ \text { West Germany } & \text { - } & 10250 \text { million } \\ \text { Belgium - . } & \text { - } & 4520 \text { million } \\ \text { Great Britain } & \text { - } & 3400 \text { million } \\ \text { France . . } & \text { - } & 280 \text { million }\end{array}$

The main industrial investments in connexion with the Ten Year Scheme were as follows:

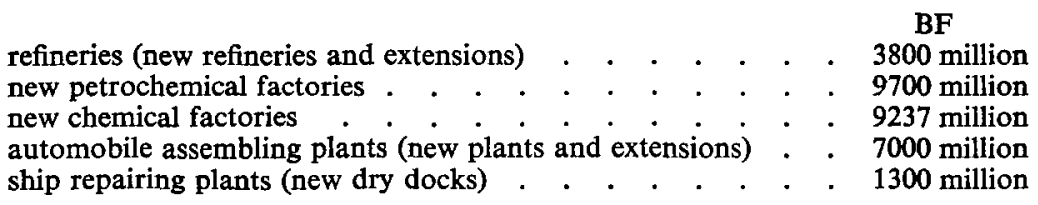

166. Today private enterprise is taking an increasing share in the investments. Before the war, and even for a few years after, the principle was that the City constructed not only whole of the infrastructure but also the greater part of the superstructure (sheds, cranes, equipment, etc.). Now we are following the example of Rotterdam where for some time private companies have equipped their own berths. In the new dock area, the southern quays of the Fifth Dock, and the whole of the Sixth Dock and of the Churchill Dock have been equipped by the stevedoring companies, the agents and other private interests.

167. The contribution made in this way by private enterprise has now reached a large figure.

\section{Net investments since 1956}

BF

Total equipment in the framework of the Ten Year Plan .

Modernization and extension of the equipment prior to the Ten Year Plan .

Industrial investments (main projects only) .

Total private investment
5301753380

800000000 31037000000

37138753380

168. However, the port of Antwerp is city owned, city managed and even partly city operated. Since it handles more than $91 \%$ of the total shipping traffic of all Belgian seaports, with regard to the relatively small size of Belgium it must be considered as being of national interest. Highways, canals and other public services are 
of national interest. The port of Antwerp, serving the whole of the country, can be considered from the same viewpoint. It is therefore quite obvious that the government should give financial aid for carrying out the necessary large works of modernization and extension. The City will not have to repay these subsidies.

169. The public investments since 1956 can be summarized as follows (figures in BF):

$$
\text { State City Total }
$$

Works in the framework of the Ten Year Plan . . . . . . .

Churchill Dock and some other minor works additional to the Ten Year Plan . . . . . . . . .

Works additional to the Ten Year Plan. Road Tunnel under Canal Dock and infrastructure works for industries.

$5927651306 \quad 167100969 \quad 6094752275$

$1011994818 \quad 116098376 \quad 1128093194$

Works for the Railways Company, railway bridge above Canal Dock .

Total public investment

\begin{tabular}{ccc} 
State & City & Total \\
5927651306 & 167100969 & 6094752275 \\
1011994818 & 116098376 & 1128093194 \\
& & \\
\hline 581425580 & - & 581425580 \\
\hline 7521071704 & 1266118336 & 8787190040 \\
\hline
\end{tabular}

Notes:

(a) Cost of expropriation of land at the charge of the City: $300000000 \mathrm{BF}$.

(b) The City invests at least $500000000 \mathrm{BF} / \mathrm{year}$ in the port.

170. A very important question is that of the size of ships which can come to Antwerp. In circumstances of good tide and weather, ships of slightly more than $41 \mathrm{ft}$ depth with a total load of, say, $71000 \mathrm{dwt}$ can use Antwerp. These were the maximum figures for 1967. We hope that in the reasonably near future we will be able to accommodate ships of $85000 \mathrm{dwt}$ and that later, if the necessary works are carried out in the River Scheldt, ships of up to about $100000 \mathrm{dwt}$ will be able to enter the port. Our reason for talking in terms of ships of $100000 \mathrm{dwt}$ is because this is likely to be the maximum size of several bulk carriers. Antwerp is a typical general cargo port, handling about 19 million tons/year. On the basis of these figures, we are on a similar level to London, Rotterdam and New York. The traffic of bulk goods is of great importance, however, and we should be very sorry to lose it through the ever increasing size of specialized ships carrying some bulk commodities.

171. The biggest ships at present used for transporting iron ore are of about $60000-70000 \mathrm{dwt}$, and in the near future the size of ships in this trade may increase to $85000 \mathrm{dwt}$. We do not know what will be the size of ships in the near future for the carriage of other bulk goods such as grain. These bulk commodities, all transported by large sea vessels, together with the traffic in crude oil, present our main problem at present.

172. The Esso, BP and Petrofina companies, which have established two big refineries (capacity 19 million tons/year) are contemplating the building of a pipeline from Rotterdam to Antwerp in order to take the crude oil from ships of over 225000 dwt, for which Rotterdam is now preparing an oil terminal. From an official standpoint, Antwerp is not in favour of this proposal. We would prefer a different solution, perhaps similar to that adopted by Gulf Oil, which has built a big oil terminal on the southern coast of Ireland. From our point of view, a more appropriate solution would be to use an oil terminal to be built at a French port such as Brest, Le Havre or Dunkirk, where ships of 300000,400000 or even $500000 \mathrm{dwt}$ can bring their crude oil and transship it into smaller tankers of, say, 85000-100 000 dwt, since these ships in the near future can call at Antwerp. This is the kind of 
solution which we would prefer. A decision will have to be made very soon by the Government.

173. In reply to Mr McGarey, the left bank of the Canal has been allocated for the whole of its length to the different industries which have settled down in the industrial area or which will do so in the near future, viz. Bayer, Degussa (the German chemical company which decided in May 1968 to come to Antwerp as well), Monsanto, Solvay, Albatros and Badische Anilin- und Sodafabrik (BASF). The right bank of the Canal will be reserved for typical port activities, as follows:

(a) B1 is for the handling of bulk goods;

(b) the embayment in B1 is a waiting dock for inland craft, barges, etc.;

(c) north of the railway bridge and the road tunnel in $\mathrm{B} 2$, two additional lateral docks can be built for the handling of general cargo, unit loads, containers, etc.

The right bank of $\mathrm{B} 3$ borders a housing development scheme.

174. A number of questions have been raised concerning the Zandvliet Lock. From comparative studies and also from the results of public tendering for Baudouin Lock it became clear that massive side walls without steel reinforcement were more expensive than the type of side wall adopted. In order to give these walls sufficient inertia to cope with impacts, the dimensions were made somewhat larger, reinforcement was inserted in the tension zone, with shrinkage reinforcement in the front face.

175. In these circumstances the maximum stresses allowed for in the calculations were rather low:

concrete stress $=711 \mathrm{lb} / \mathrm{sq}$. in.

steel stress $=17065 \mathrm{lb} / \mathrm{sq}$. in.

For the side walls and the heads a concrete cover of 4 in. was prescribed. Elsewhere a minimum cover of 2 in. was specified.

176. Since the side walls were calculated as separate walls, the actual floor was considered as a mere screen-floor, in order to avoid excess depths being caused by dredging works in the lock chamber. The floor is composed of rectangular concrete tiles, measuring $40 \mathrm{ft} 2 \mathrm{in} . \times 36 \mathrm{ft}$, with reinforced edges. In order to prevent flotation vertical drainage openings $10 \mathrm{in}$. in diameter were left, and these were filled with drainage material. Under the tiles a continuous horizontal drain was installed so as to prevent the sand being sucked away.

177. The cut-off between lock and dock is effected by a screen of steel sheet piling, driven 18-28 ft lower than the lock bottom and completely encircling the inner head. During preliminary discussions an agreement was reached on the following points:

(a) twin gates would be constructed at each head;

(b) it would be undesirable to build an intermediate head, because of the great number of ships to be passed through within a minimum lapse of time, dependent upon the tide in the river.

178. The system for filling and emptying the lock chamber had already been thoroughly studied in relation to the construction of the Baudouin Lock. The following points were then put forward:

(a) the culverts for filling and emptying the lock chamber should be as short as possible, in order to simplify the construction of the side walls; this should not, however, diminish the useful length of the lock;

(b) the tensions in the mooring ropes of ships must be kept to a minimum;

(c) the filling time, at a water level difference of $13 \mathrm{ft}$, must be restricted to $15 \mathrm{~min}$. It was unnecessary to specify a lower filling time as greater time-losses occur during sluicing operations, for a variety of other causes. 
Tests showed that by using short culverts all these requirements could be fulfilled if the outlet openings in the lock chamber were spaced at a low level near the bottom, so as to convey the water flow under the keels of the ships.

179. The results obtained in the Baudouin Lock were satisfactory, and after preliminary scale-model tests the same system was adopted for the Zandvliet Lock.

180. Each of the four gate chambers is designed in such a way that it can be pumped dry and used as a dry dock for inspection and maintenance of gates and rails. To do this a floating steel caisson is brought to site, and lowered vertically in front of the chamber. It has rubber contact cushions at the bottom and wood lining at each side and thus is effectively watertight. The same caisson can be used for each of the four chambers. After the caisson is in position, the water is pumped out of the gate chamber by centrifugal pumps, installed in a pumping pit, spaced out in the concrete wall between the twin chambers. The water is pumped either to the docks or to the river.

181. For inspection of the bottom rails in the lock at Baudouin Lock a horizontal U-shaped tunnel attached to the track on the lock bottom is used. This tunnel is watertight at one end and the other end, connected to the gate chamber, is open and shaped in such a way that the caisson can be attached to it. As soon as this has been done, the gate chamber and the connecting space above the bottom rails can be pumped dry. It is then possible to perform a thorough inspection in normal atmospheric pressure. The height of the horizontal tunnel is reduced to a minimum, so that, even with the tunnel in place, the lock remains in service. A similar tunnel is to be built for the Zandvliet Lock.

182. In order to assist the desalination of the newer docks, an excess depth of $63 \mathrm{ft}$ was dredged off the inner head in the swinging basin, into which the most saline water sinks by gravity. This 'salt layer' can at low tide (water level difference between dock and river is then about $15 \mathrm{ft}$ ) be conveyed to the Scheldt through a twin tube duct, measuring $2 \mathrm{ft} 9 \mathrm{in} . \times 11 \mathrm{ft} 10 \mathrm{in}$. The intake of this duct is situated in the area of excess depth, under the lock sill and it has eight openings, each measuring $17 \mathrm{ft} \times 7 \mathrm{ft} 6 \mathrm{in}$. The outlet in the northern quay wall of the access channel (river side) has been designed in such a way that hindrance to ships in this channel during operation of the duct is kept to a strict minimum. The type of intake and outlet were chosen after scale-model tests in the Hydraulics Laboratory at Borgerhout.

183. Calculations have shown that with single tube operation, about $35315000 \mathrm{cu}$. ft of water can be transported during one tide. The maximum flow amounts to 1377 cusecs and the section of the intake is calculated in such a way that, at this rate of flow, the maximum intake velocity of the water is about $1 \mathrm{ft} 4 \mathrm{in} . / \mathrm{s}$. Tests have shown that at greater intake velocities aspiration of the higher fresh water layer may occur. When both tubes are used at low tide, the intake velocities are increased to $2 \mathrm{ft} 8 \mathrm{in} .-3 \mathrm{ft} 4 \mathrm{in} . / \mathrm{s}$. This permits the silt heaped up in front of the intake openings to be sucked away.

184. The total cost of the lock, including electro-mechanical equipment and dredging works, amounts to $£ 17916000$. This figure includes:

actual lock with quay walls in access channel and abutments for bridges at inner and outer head:

electro-mechanical equipment (including bridge at inner head):

dredging works in access channel and swinging basin:

$£ 11250000$

$£ 2916000$

$£ 3750000$

A detailed publication on the Zandvliet Lock will be issued shortly by the Ministry of Public Works.

185. In the present circumstances the warranted depth over the sills in the approaches to the Zandvliet Lock is $28 \mathrm{ft} 11$ in. under ODG (Zéro Dépôt de Guerre). In the future, depths will, if possible, be increased to $30 \mathrm{ft} 6 \mathrm{in}$. DG, while in case of execution of the Verschave project, including a cut through the inundated land of Saaftinge, depths of $32 \mathrm{ft} 10$ in. DG would be attainable. 


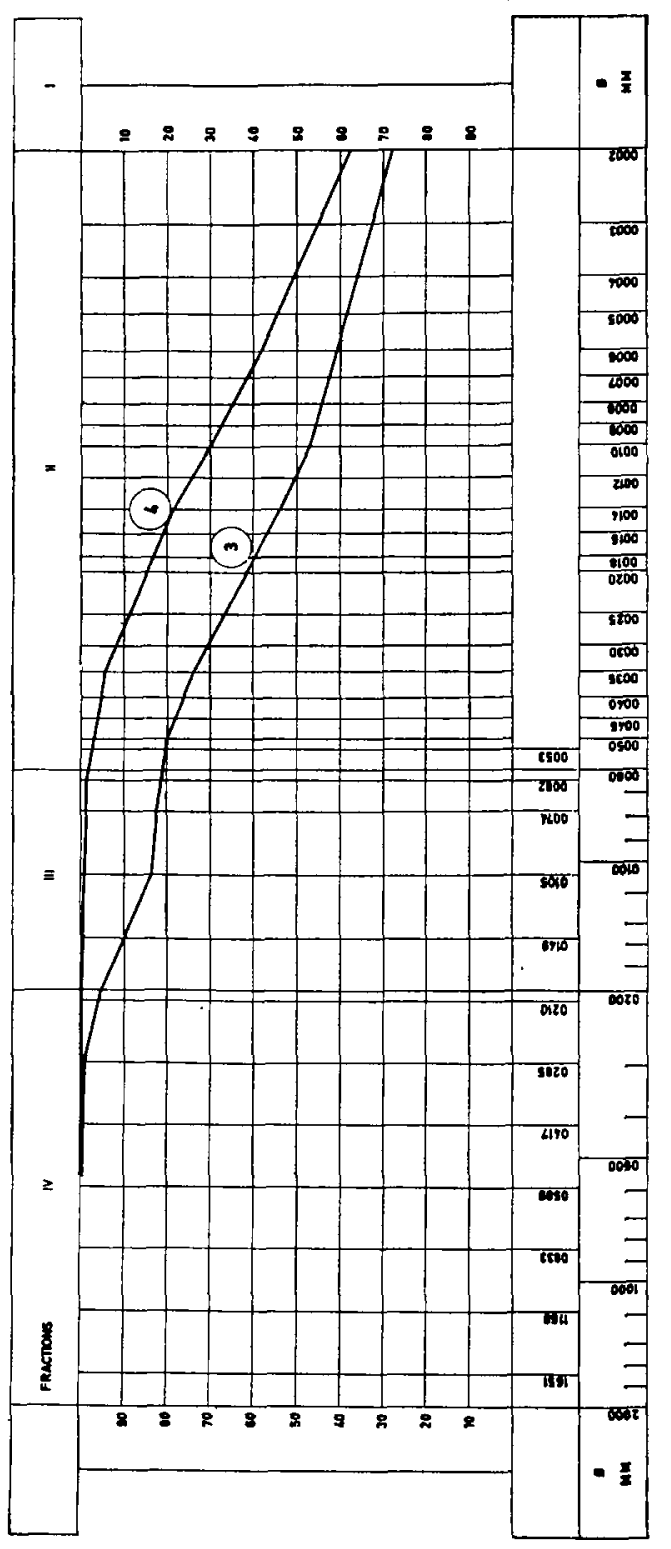

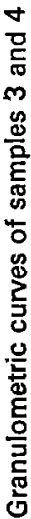

SgOYLAgOZZd NI ALILNYNO OZABIS

$\stackrel{\circ}{\circ}$

i்

Downloaded by [] on [26/04/23]. Copyright (C) ICE Publishing, all rights reserved. 
NATURAL TERRAIN

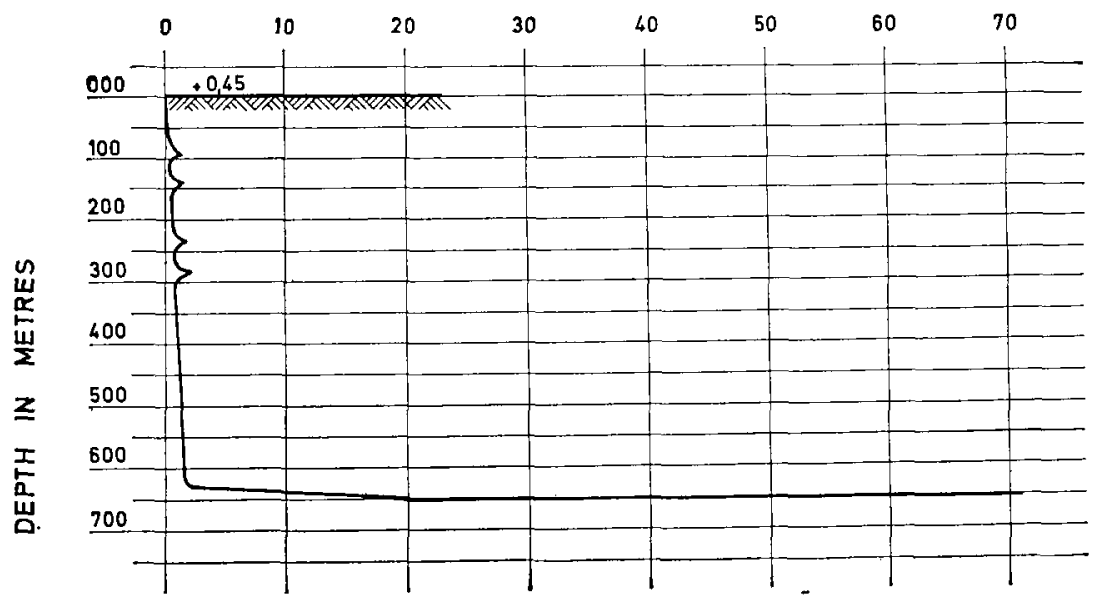

Fig. 17. Point resistance in $\mathrm{kg} / \mathrm{sq} . \mathrm{cm}$

Table 2

\begin{tabular}{|c|c|c|c|c|c|}
\hline \multicolumn{2}{|l|}{ Characteristics } & \multicolumn{4}{|c|}{ Sample } \\
\hline & & 1 & 2 & 3 & 4 \\
\hline 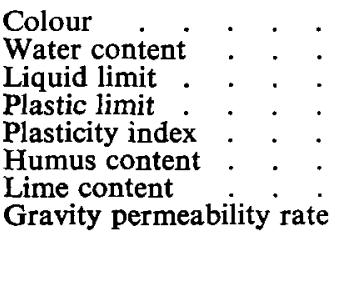 & 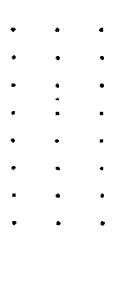 & $\begin{array}{c}\text { blue } \\
122 \% \\
91.6 \% \\
31.8 \% \\
59 \cdot 8 \\
5.55 \% \\
30.7 \% \\
1.82-2.07 \\
\times 10^{-7} \\
\mathrm{~cm} / \mathrm{s}\end{array}$ & $\begin{array}{c}\text { black } \\
220 \% \\
160.9 \% \\
54.7 \% \\
106 \cdot 2 \% \\
12.6 \% \\
24.9 \% \\
4.24-4 \cdot 1 \\
\times 10^{-7} \\
\mathrm{~cm} / \mathrm{s}\end{array}$ & $\begin{array}{l}- \\
-\overline{124 \cdot 5 \%} \\
70 \cdot 8 \% \\
53 \cdot 7 \\
6 \cdot 4 \% \\
28 \cdot 8 \%\end{array}$ & $\begin{array}{l}-\overline{ } \\
99 \cdot 9 \% \\
39 \cdot 0 \% \\
60 \cdot 9 \\
2 \cdot 6 \% \\
37 \cdot 2 \%\end{array}$ \\
\hline
\end{tabular}

186. Mr Page asks for details of the effect of the Kjellman drains. Four samples of Grote Geul silt have been analysed at the Laboratory of the State Geotechnical Institute. The results are given in Table 2. (See also Fig. 16.)

187. These data show that the silt of the Grote Geul consisted of an organic and silty type of clay with a considerable calcareous content. This clay, the characteristics of which varied somewhat from one spot to another, had a water content which exceeded by far the liquid limit and it was, as a result, of a semi-liquid consistency. This accounts for the very slight incline of the slopes during the excavation.

188. The point resistance was measured by means of a hand penetration test carried out at the crossing of the Canal Dock and the Grote Geul. In the layer of silt, the point resistance fluctuated between 1 and $2 \mathrm{~kg} / \mathrm{sq} . \mathrm{cm}$. 
189. When computing the water contents of the silt after consolidation by means of Kjellman drains it was found that, after this operation, the liquidity index was reduced from values above 1 to values between 0.85 and 0.98 . The latter values were still very high. They showed that when, as a result of consolidation, the clayey silt was brought from semi-liquid to plastic condition, the cutting conditions of the silt remained very mediocre, even after draining. Under such circumstances the opening of an excavation could only take place if provision was made for very flat slopes, so that the consolidation would then have had to be carried out over a much more considerable width than originally foreseen.

190. This is the reason why it was decided to apply electro-osmosis, so as to create stabilizing electric pressures, intended to allow the execution of steeper slopes in the silt. A typical result is given below.

\begin{tabular}{|c|c|c|c|}
\hline San & & 1 & 2 \\
\hline $\begin{array}{l}\text { Resistivity in ohm } / \mathrm{cm} \\
\text { Rate of electro-osmotic } \\
\text { sq. } \mathrm{cm} / \mathrm{s} \mathrm{V} .\end{array}$ & permeability $k e^{\cdot}$ in & $\begin{array}{c}322 \text { to } 361 \\
3 \text { to } 5 \times 10^{-5}\end{array}$ & $\begin{array}{c}185 \text { to } 395 \\
3 \text { to } 10 \times 10^{-5}\end{array}$ \\
\hline
\end{tabular}

191. In order to produce for the additional stabilization a sufficient quantity of earth, three rows of electrodes with interspaces of $16 \mathrm{ft} 9 \mathrm{in}$. were provided; the distance between the electrodes in the same row was $10 \mathrm{ft}$. In order to initiate the stabilizing electric pressures for the slopes, the electrodes of the row closest to the excavation were all positive. In the other two rows, the electrodes were alternately positive and negative.

192. Thanks to the accelerated consolidation obtained by the use of KjellmanFranki drains and the stabilizing electric pressures created by the application of electro-osmosis, it has been possible to excavate as deep as the lower part of a semiliquid clayey silt which in its natural state had a slope of less than $5 \%$. In the layer of silt, which was initially $23 \mathrm{ft}$ thick, the excavations could be executed with normally inclined slopes; about $45 \%$ in sand, and almost vertically in silt.

193. After the excavation had been carried out, it was possible to build the quay walls in the same way as in the other sections.

194. The Kjellman machine used for placing the cardboard drains was semiautomatic.

195. The cost of these works, which included the execution of 25750 cardboard drains with an average length of $32 \mathrm{ft} 2 \mathrm{in.}$ (total length of the placed drains: $830000 \mathrm{ft}$ ), the placing of 88 cathodes, 172 anodes and all the equipment necessary to the functioning of the electro-osmosis, such as electric conductors, pumps, etc. amounted to approximately $£ 64166$.

\section{References}

1. Port of Dunkirk. La nouvelle écluse maritime.

2. Giraudet P. Évolution et transformation du port du Havre. Nav. ports chant. 1967 No. 203 (April) 288-295.

3. Parke E. G. Pipelines and tankers: two complementary forms of oil transportation. Tijdschrift Vervoerswetenschap, Rotterdam, 1967, No. 4.

4. Smeardon R. F. J. et al. Engineering Works at Tilbury Dock, 1963-67. Proc. Instn civ. Engrs, 1967, 38 (Oct.) 177-228. 